Egyptian

Orthodontic Journal

\title{
PREDICTION OF ROOT RESORPTION AND PERIODONTAL TISSUE CHANGES ASSOCIATED WITH RAPID MOLAR INTRUDER
}

\author{
Eman M. Elsayed ${ }^{1}$, Fatma Abdel-Aziz ${ }^{2}$, Mai Shafik ${ }^{3}$
}

\section{ABSTRACT:}

Objective: Rapid molar intruder appliance (RMI), was used to close the anterior open bite by intruding upper and lower first molars. The aim of the present study was to investigate the amount of root resorption of first molars, as well as periodontal tissue changes associated with the application of RMI. Methods: Eleven female patients (mean age; 13-15 years) were included in the study. They had ANBB angle average 5 degrees, with anterior open bite 1-3 mm. Root resorption and bone density were assessed using DBS win software, analyzing serial periapical radiographs of the first molars. Periodontal tissue changes were evaluated by measuring the probing depth, and sulcus bleeding and plaque indices. The records were compared with those of healthy, nonorthodontically moved first molars. Results: The upper first molar was intruded $1.9 \mathrm{~mm}$, with $0.63 \mathrm{~mm}$ root resorption. While the lower molar intruded 0.5-0.7 mm, with root resorption of $0.7 \mathrm{~mm}$. No significant change in the periodontal variables was found. Conclusion: Rapid molar intruder is an efficient appliance for treating anterior open bite, causing minimal root resorption and maintaining the health of periodontium. The upper first molar is more favorable to be intruded, with significantly less apical root resorption, than the lower one.

1- Lecturer at the Orthodontic Department, Faculty of Oral and Dental medicine, Cairo University.

2- Lecturer at the Orthodontic Department, Faculty of Oral and Dental medicine, El-Azhar University (Girl's branch).

3- Lecturer at the Oral medicine, Periodontology and Radiology Department, Faculty of Oral and Dental medicine, Misr international University. 
Egyptian

Orthodontic Journal

\section{INTRODUCTION}

Success of an orthodontic appliance is measured by its efficiency of treatment with minimal deleterious effects on the patient. Rapid molar intruder appliance (RMI) had been introduced since 2002. ${ }^{1}$ Its capability of intruding posterior teeth in anterior open-bite patients was documented. It intruded the upper and lower molars about $1.8 \mathrm{~mm}$ in growing patients in 5 months. ${ }^{2}$ Its force level started with $800 \mathrm{~g}$ and decayed to $250 \mathrm{~g}$ by time. ${ }^{3}$

Orthodontically induced inflammatory root resorption (OIIRR), is an inevitable pathological consequence of orthodontic tooth movement that compromises the success of orthodontic treatment. Causative factors may be biological or mechanical. Some mechanical factors include the magnitude of applied force, duration and direction of force application, type of tooth movement and type of orthodontic appliance used. Mechanical factors can be controlled by clinician or patient or both. ${ }^{4}$ The longer the force duration, ${ }^{5-9}$ and the heavier the force magnitude, ${ }^{4,7,9,10-14}$ the greater the volume of root resorption. Other investigations reported that duration of a continuous applied force is more critical than the force magnitude in producing root resorption. ${ }^{15,16}$ Intrusion is probably the most detrimental type of tooth movement, to the roots involved. ${ }^{17,18}$ Fixed appliances can affect the periodontal tissues, ranging from gingivitis to aggressive bone loss.

Rapid molar intruder is a fixed orthodontic appliance that causes molar intrusion. Thus, its effect on root resorption, as well as, periodontium will be evaluated in the present study.

\section{Sample and Methods:}

\section{I) Sample:}

The sample of the study included the evaluation of maxillary and mandibular first molars intruded with rapid molar intruder (in the experimental group) compared with non-orthodontically moved ones (control group). Ethics approval was obtained from the Research Ethics committee of Faculty of Oral and Dental medicine, Cairo University. 
Egyptian

Orthodontic Journal

A) Experimental group:

Eleven females of ages 13-15 years, with anterior open-bite and class I or class II division 1 malocclusion were selected, (Fig. 1). They had no previous orthodontic treatment. Criteria of selection include; skeletal class I, fully erupted upper and lower first molars, no sucking habits, no need of tonsillectomy, nor adenoidectomy. ANB between 2 and 8 degrees. GoGn-SN angle was greater than 37 degrees. Pre and posttreatment orthodontic records were taken for each patient. The orthodontic records included study models, facial and intraoral photographs, lateral cephalometric and panoramic x-ray films. Periodontal records included; plaque index, sulcus bleeding index and probing depth. Root resorption; including root length and surface area, and bone density changes were evaluated using digital radiographs.
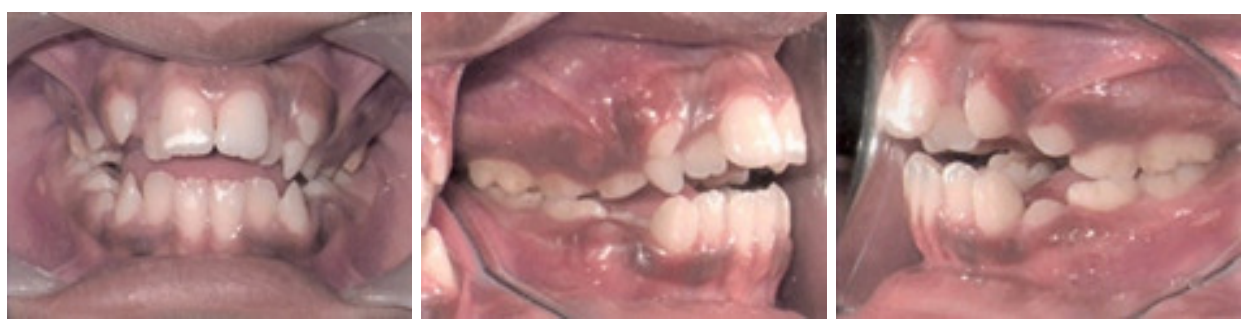

Figure (1): Pretreatment intra-oral photographs of a 12 years old female with $3 \mathrm{~mm}$ anterior open-bite.

B) Control group:

It included fifteen female patients, age 13-15 years, seeking other operative procedures to teeth other than first molars. Their maxillary and mandibular first molars were evaluated regarding the previous records mentioned in experimental group. The evaluation was done once the sample was collected and six months later.

\section{II) Methods}

A) Rapid molar intruder appliance: ${ }^{2}$ (Fig. 2)

The appliance consisted of one spring module and two ball connectors per side. The terminal ends of the flexible spring modules are designed to attach the ball connectors, which were inserted into lip 
bumper tubes welded on molar bands. The intrusion force created by the flexion of the elastic spring modules transferred to the maxillary and mandibular first molars, when the patient closes the jaws. Buccal tipping of upper and lower molars was avoided using trans-palatal and lingual arches, respectively. The trans-palatal arch was constructed to be $2 \mathrm{~mm}$ away from the palatal tissues. The intrusive force was about 800-1000 grams, each side. The patients were scheduled every four weeks, to check appliance in place. The appliance will be applied until 1-2 $\mathrm{mm}$ of anterior overbite is achieved. Extraction of deciduous molars and canines was done, once their contact on occlusion was observed, to allow continuity of bite closure.

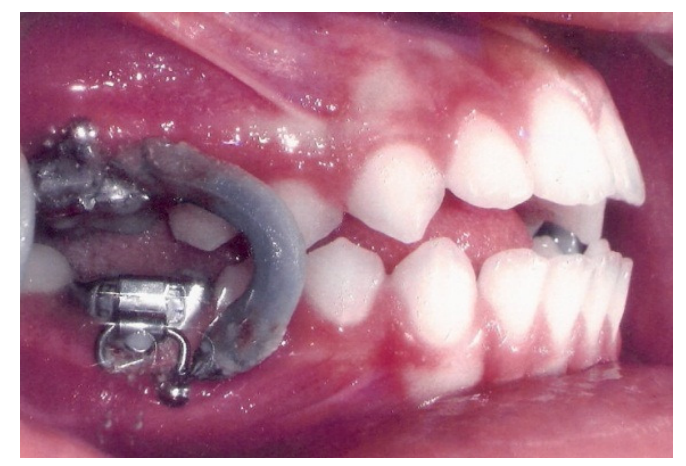

Figure (2): Rapid molar intrusive appliance, applied at the upper and lower first molars.

B) Methods of evaluating periodontal tissue changes:

1) Probing depth: was measured using William's probe.

2) Sulcus bleeding index: recorded according to Muhlemann and Mazor (1958), ${ }^{20}$ one recorded for facial surface and the other for the lingual one.

3) Plaque index: recorded according to Loe and Silness 1963.

Root resorption and bone density were assessed using the DBS win software, which is a part of a recently introduced vista scan system. The sensor of the digital radiograph was exposed by the ORIX x-ray machine (Orix-5 mobile X-ray machine, ARDET Srl, Italy) ${ }^{\mathrm{TM}}$ at 6.5 kilovolt and $\mathrm{mA}$ for 0.04 seconds. The exposure parameters were fixed for all patients and for the follow up period. Serial standardized periapical radiographs 
were made using the long cone paralleling technique. ${ }^{21}$ The mean gray value in each region of interest was calculated at 256 gray levels of colors resolution. This was done by assigning gray value (0) to black and (256) to white. ${ }^{22}$

Root resorption was expressed as changes in root length and root surface area (Fig. 3). ${ }^{23}$ The root length for each root was measured by a line plotted from cusp tip (as reference point) to the root apex. The root surface area was measured by calculating the area within the trapezoid sides; mesial and distal roots, line representing the cement-enamel junction (CEJ) and the line joining the two apices of the roots.
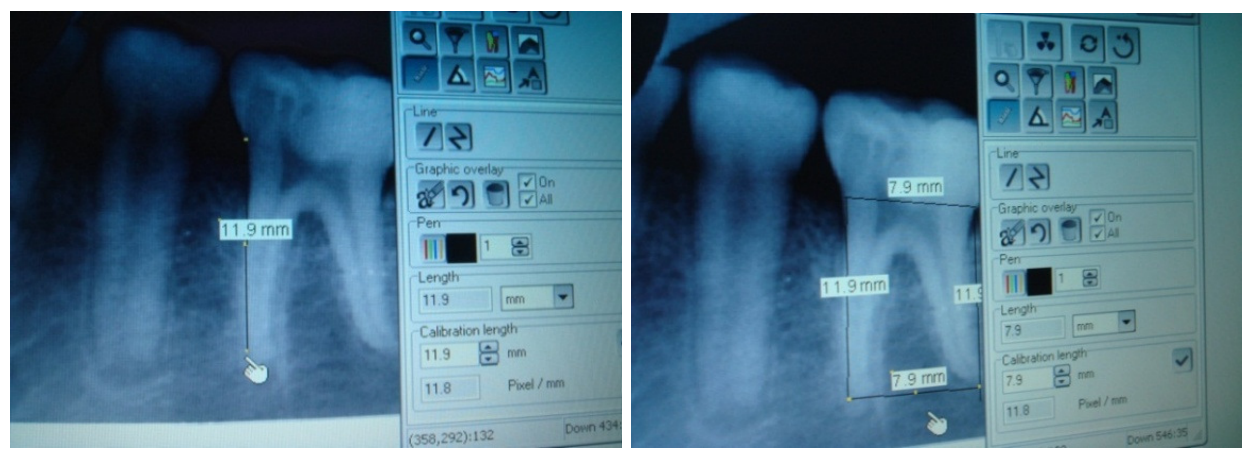

Figure (3): DBS software used to record the root length (left) and the root surface area (right).

Lateral cephalometric radiographs were taken to measure the following: ${ }^{2}$

a) Angular measurements: SNA, SNB, Go Gn-SN SN-U1, SN-U6, MPL1, MPL6, and Occlusal/SN plane.

b) Linear measurements: incisor superius/incisor inferius, U6/PP, L6/md plane, U1/PP, L1/ md plane, Wit's appraisal, and ANS-occlusal plane.

The centroid of the teeth was used to evaluate their linear movements. ${ }^{24-26}$ Also the measurements were recorded for the upper and lower, as well as right and left first molars. The records of the experimental teeth were compared with control groups of the same period of experiment; six months. Both pre- and post-treatment radiographs were retraced and re-measured by the same investigator to ensure measurement accuracy.

Volume 42-December 2012 
Egyptian

Orthodontic Journal

\section{STATISTICAL ANALYSIS}

Statistical analysis was performed using Statistical package for social sciences, version 18 (SPSS 18). First, all variables were tested for normality using Kolmogrov Smirnov test. If the test was significant, non-normality was accepted. Quantitative variables were presented as means and standard deviations, when normality assumptions were satisfied. Paired T- test was done to show statistical significance for difference between pre and post treatment, and between treatment and control groups. Confidence interval $95 \%$ for difference was done with upper and lower level mentioned. Treatment changes in each group were evaluated by the Wilcoxon signed rank test. A comparison of the mean changes between the groups was done by the Kruskal-Wallis test. The level of significance was established as $\mathrm{P}<0.05$ for all the statistical tests.

\section{RESULTS}

The movement changes of the upper and lower first molars, as well as incisor teeth, are presented as the mean and standard deviation of the pre-treatment and post-treatment measurements, (Table 1). The centroid point was used to interpret the linear measurements of teeth. While the angular or tipping movements were recorded using their long axes. The upper first molar was intruded about $1.9 \mathrm{~mm}$, with mesial tipping of 4 degrees. The lower first molar extruded $0.5 \mathrm{~mm}$ with distal tipping of 1 degree. The upper incisor extruded $3 \mathrm{~mm}$, and the lower one $3.6 \mathrm{~mm}$. The closure of the anterior open-bite was about $3 \mathrm{~mm}$, presented by the decrease in the incisor superious to incisor inferious measurement. No significant change was found between the pre and post treatment measurements, of all the skeletal variables. While significant change was recorded at the upper and lower incisor movements denoted by, U1/PP and L1/md plane, respectively. Non- significant change was found between the rest of the linear variables. 
Egyptian

Orthodontic Journal

Table (I): Cephalometric measurements showing the pre-treatment and post-treatment mean and standard deviation.

\begin{tabular}{|l|c|c|c|c|}
\hline \multirow{2}{*}{ Cephalometric Measurements } & \multicolumn{2}{c|}{ Pre - Treatment } & \multicolumn{2}{c|}{ Post - Treatment } \\
\cline { 2 - 5 } & Mean & SD & Mean & SD \\
\hline Angular & 80.1 & 4.3 & 82 & 3.4 \\
\hline SNA & 75.3 & 4.4 & 77.3 & 5.2 \\
\hline SNB & 48 & 8.8 & 49.5 & 9.0 \\
\hline GOGN-SN & 72.8 & 9.3 & 73.8 & 9.3 \\
\hline SN - U1 & 105.1 & 19.3 & 101 & 18.1 \\
\hline SN- U 6 & 105.6 & 9.8 & 102 & 9.8 \\
\hline Mp- L1 & 104.9 & 13.5 & 104 & 10.1 \\
\hline Mp - L6 & 21.2 & 1.8 & 25 & 2.5 \\
\hline OCCLUSAL/SN plane & & & & \\
\hline Linear & 2.9 & 1.8 & -0.4 & 1.6 \\
\hline Incisor superius/ Inferius & 12.5 & 3.9 & 10.6 & 3.6 \\
\hline U6 /pp & 19 & 1.6 & 18.5 & 1.4 \\
\hline L6/md plane & 15.4 & 2.8 & 18.3 & 3.5 \\
\hline U1/pp* & 26.9 & 3 & 30.6 & 4.2 \\
\hline L1/ md plane* & & &
\end{tabular}

* Significant at $\mathrm{p}<0.05$

The experimental variables measured are presented as the treatment changes, rather than the mean and standard deviation of pre-treatment and post-treatment measurements, (Table 2). No significant difference was found between the molars and control groups, regarding the probing depth and gingival and plaque indices. The root resorption was recorded as the changes in root length as well as root surface area. There was also non-significant difference between the three groups regarding the amount of root resorption. High significant difference was found between the molar teeth and the control group, regarding the density of the alveolar bone. 
Table II: The treatment change values of the upper first molar and lower first molar teeth compared with control group.

\begin{tabular}{|l|c|c|c|c|}
\hline \multicolumn{1}{|c|}{ Variables } & Upper first Molar & Lower first Molar & Control & Significance \\
\hline Probing depth & 0.51 & 0.75 & 1.33 & NS \\
\hline Gingival index & 0.75 & 0.75 & 1 & NS \\
\hline Plaque index & 1 & 0.5 & 0 & NS \\
\hline Root length & -0.28 & -0.35 & 0.35 & NS \\
\hline Root Area & 0.65 & 0.18 & 0.25 & NS \\
\hline Bone density & 24.75 & 26.75 & 5.33 & $(*)$ \\
\hline
\end{tabular}

${ }^{(*)}$ Significant at $\mathrm{p}<0.05$

NS: non- significant.
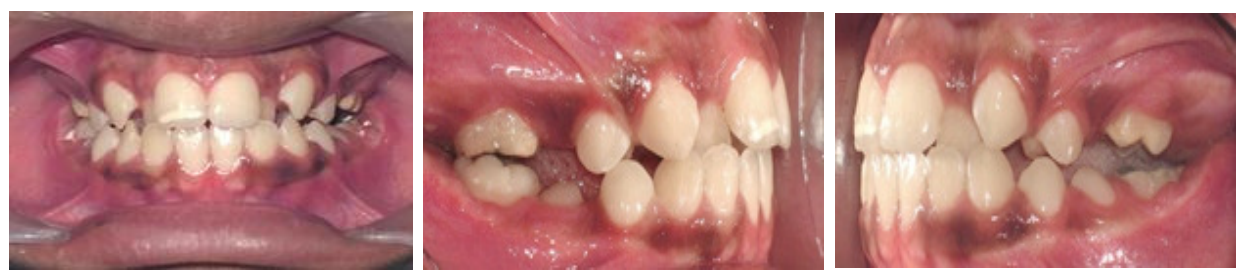

Figure (4): Post treatment, intra-oral photographs following the intrusion of the first molars and anterior bite closure of the 12 year old female.

\section{DISCUSSION}

Minimal root resorption was identified at the apex of the roots of maxillary and mandibular first molars, intruded by rapid molar intruder. Good oral hygiene and healthy periodontium were maintained during the intrusion procedure.

The study was implied on females only, as some studies found variation of root resorption within different genders, ${ }^{17}$ while most studies found no difference. ${ }^{27}$ The GoGn-SN of the selected open-bite patients was more than 37 degrees, and 1-3 $\mathrm{mm}$ bite opening at the anterior teeth. ${ }^{1,228}$ To measure the amount of first molar movement, as well as 
Egyptian

Orthodontic Journal

central incisors of both arches, the centroid point was used as the reference. The centroid is a point on the longitudinal axis of the tooth that is independent of any changes in inclination. ${ }^{24-26}$ It was claimed that using occlusal or apical points of molars to evaluate its intrusion can increase or decrease the amount of tipping movement, if tipping is part of molar movement. ${ }^{29,30}$ True molar intrusion of the maxillary first molar was $1.9 \pm 0.9 \mathrm{~mm}$, with mesial tipping of 4 degrees. While, the lower first molar was intruded $0.5 \pm 0.2 \mathrm{~mm}$, with 0.9 degrees distal tipping. In previous studies, ${ }^{1,2,28,31}$ the rapid molar intruder, intruded maxillary first molar about $1.86 \mathrm{~mm}-2.54 \mathrm{~mm}$, and the lower was intruded $1.04-1.52$ $\mathrm{mm}$. This slight variation in molar movements was due to difference in reference points taken, where those previous studies used the cusp tips rather than centroid. First molar intrusion, was $2.3 \pm 1.3 \mathrm{~mm}$ in the upper arch, and $0.8 \pm 1.3 \mathrm{~mm}$ in the lower one, utilizing implant for anchorage. ${ }^{32}$ Other studies, claimed that mini-implants caused about 3-4 mm molar intrusion. ${ }^{29}$ Previous studies claimed that, RMI caused true intrusion ${ }^{3}$ and not relative intrusion as by other appliances as headgear and bite blocks. ${ }^{33,34}$ The over bite was closed $3 \mathrm{~mm}$, whereas, in normal growth, over bite changes were only minimal; $0.2 \mathrm{~mm}$, in children from $10-15$ years. ${ }^{35}$

The radiographic bone measurement is a non-invasive, painless, alternative method to measure bone changes. In this study, Vista scan system was used to monitor alveolar bone change. This system uses the DBS-win software with a phosphor image plate producing images following exposure. This requires lower radiation dose and has the capability of computer image analysis. ${ }^{23}$ Bone density was the only value that significantly increased, denoting the great bone turn over taking place due to tooth movement.

Probing depth, plaque and bleeding indices of the upper and lower first molar teeth, improved in this study. Melsen et al., ${ }^{36}$ investigated tissue reaction to orthodontic intrusion with reduced periodontium on macacafasicularis monkeys. They found that intrusion improved the quantity of new attachment, if carried out under healthy conditions. These results also agreed with several studies, ${ }^{37-40}$ but disagreed with 
others. ${ }^{41}$ Huser et al., ${ }^{42}$ claimed that there were definite increases in plaque scores and probing depths in patients with fixed appliances. Others, ${ }^{19}$ encountered deleterious effects ranging from gingivitis to bone loss and even gingival recession. This variation in results from the present study, could be due to the variation in appliance used, where in this study only rapid molar intruder appliance was induced, allowing the easy access of teeth cleansing and care. Thus, if wherever possible the appliance be applied, part by part, without prolonging the treatment time rather than placing the whole fixed appliance at once. This would be more favorable for the periodontal health of the patient.

Root resorption was identified radiographically at the upper and lower first molars; $0.63 \mathrm{~mm}$ and $0.7 \mathrm{~mm}$, respectively, taking into consideration normal root lengthening in the control group. The degree of resorption was considered to be minor, ${ }^{43,44}$ as resorption is less than 2 $\mathrm{mm}$. The force of intrusion by the rapid molar intruder was heavy at the start of treatment; $800 \mathrm{~g}$, on each side, decaying to $450 \mathrm{~g}$ by the end of the first week, then $250 \mathrm{~g}$ by the end of the second week. Studies claimed that duration of force is critical in affecting the amount of root resorption. ${ }^{5-9,45-49}$ Hendix stated that root resorption of posterior teeth, occurs independent of duration of treatment. ${ }^{50}$ Magnitude of force was also agreed to affect degree of root resorption, ${ }^{4,7,9,10-14}$ but others disagreed 51. In this study, both long duration of treatment; 5-6 months, as well as high force values; $250 \mathrm{~g}$, led to the root resorption. Inspite of that, still the amount of resorption is considered minimal, that could be repaired without affecting the tooth function. Intrusion movement is probably the most detrimental to the roots involved, ${ }^{52-55}$ but tipping, lingual root torque, bodily movement and palatal expansion can also be implicated. ${ }^{52}$ The amount of intrusion itself did not affect the degree of root resorption. This is evidenced by the amount of intrusion that is more in the upper; $1.9 \pm 0.9 \mathrm{~mm}$, than in the lower; $0.5 \pm 0.2 \mathrm{~mm}$. The same degree of root length change occured in both arches, inspite of the more intrusion that occurred in the upper one. This disagreed with Mc Fadden, ${ }^{17}$ denoting that root shortening in the maxilla is more than in mandible, but in his study he was testing all the teeth (including incisors) and not the molars 
specifically. Consequently, the high density of bone in the posterior region, could have an effect in designating degree of resorption, where it is more dense in lower, leading to more resorption than the upper. The total root area, was more in the upper than the control group, and least at the lower molar teeth. This could be an indication of more root repair and cemental deposition in other areas, as mesial and distal surfaces than the apical area, to compensate for the root resorption, apically. In conclusion, the upper molar is more favourable to be intruded than the lower one, due to more intrusive movement, less root resorption and more root repair.

The bite closure is partly due to molar intrusion and more to incisor extrusion. The molar movement might have stopped at a certain level and incisor movement continued the process. In previous studies, root repair started one week after the tooth movement ceased, but not exactly detected when in this study. ${ }^{56,57}$ This could explain why the root area was more in the intruded upper molar than control one, as repair could have took place following the resorption. A simulation of the stress response in the periodontium of the maxillary first molar, demonstrated high stress concentration on root surface ${ }^{58}$ at the furcation and not root apex as anterior teeth. This result might suggest that the root morphology of the maxillary first molar made it less susceptible to apical root resorption relative to anterior teeth during tooth movement. Further studies are needed to test the resorption at furcation area of the intruded first molars, and whether it could affect the tooth function.

\section{CONCLUSION}

The following conclusions could be drawn from the present study:

1) Rapid molar intruder is an effective appliance for the treatment of anterior open bite. It is considered biologically favorable, as it caused minimal root resorption and maintained the health of periodontium.

2) The upper first molar showed significantly more intrusive movement (about four times) than the lower one.

3) The upper first molar had minimal detrimental effect, evidenced by less apical root resorption and more root area, than the lower molar tooth. 
Egyptian

Orthodontic Journal

\section{REFERENCES}

1. Carano, A.; and Machata, W.; Sicilian, G.:Non compliant treatment of skeletal open bite. Am J Orthod Dentofacial Orthop 2005; 128:781-86.

2. Çinsar, A.; Alagha, A.R.; and Akyalçin, S.: Skeletal open bite correction with rapid molar intruder appliance in growing individuals. Angle Orthod 2007; 77: 632-39.

3. Carano, A.;Siclinai, G.;and Bowman, J.: Treatment of skeletal open bite with a device for rapid molar intrusion: A preliminary report. Angle Orthod 2004; 75:615-25.

4. Wu, A.T.J.; Turk, T.; Colak, C.; Elekdag-Turk, S.; Jones, A.S.; Petocz, P.; and Darendeliler, M.A.: Physical properties of root cementum: Part 18. The extent of root resorption after the application of light and heavy controlled rotational orthodontic forces for 4 weeks: A microcomputed tomography study. Am J Orthod Dentofacial Orthop 2011; 139:e495-e503.

5. Reitan, K.: Initial tissue behavior during apical rootresorption. Angle Orthod 1974; 44:68-82.

6. Harry, M.R.; and Sims, M.R.: Root resorption in bicuspid intrusion. A scanning electron microscope study. Angle Orthod 1982; 52:235-58.

7. Vardimon, A.D.; Graber, T.M.; Voss, L.R.; and Lenke, J.: Determinants controlling iatrogenic external root resorption and repair during and after palatal expansion. Angle Orthod 1991; 61:113-22.

8. Gonzales, C.; Hotokezaka, H.; Yashimatsu, M.; Yozgatian, J.H.; Darendeliler, M.A.; and Yoshida, N.: Force magnitude and duration effects on amount of tooth movement and root resorption in the rat molar. Angle Orthod 2008; 78:502-9.

9. Paetyangkul, A.; Türk, T.; Türk, S.E.; Jones, A.S.; Petocz, P.; Cheng, L.L.; and Darendeliler, M.A.: Physical properties of root cementum: Part 16. Comparisons of root resorption and resorption craters after the application of light and heavy continuous and controlled orthodontic forces for 4,8, and 12 weeks. Am J Orthod Dentofacial Orthop 2011; 139:e279-e284. 
10. King, G.J.;and Fischlschweiger, W.: The effect of force magnitude on extractable bone resorptive activity and cemental cratering in orthodontic tooth movement. J Dent Res 1982; 61:775-9.

11. Brudvik, P.; and Rygh, P.: Root resorption beneath the main hyalinized zone. Eur J Orthod 1994; 16:249-63.

12. Faltin, R.M.; Faltin, K.; Sander, F.G.; and Arona-Chavez, V.E.: Ultrastructure of cementum and periodontal ligament after continuous intrusion in humans: a transmission electron microscopy study. Eur J Orthod 2001; 23:35-49.

13. Harris, D.A.; Jones, A.S.; and Darendeliler, M.A.: Physical properties of root cement:Part 8. Volumetric analysis of root resorption craters after application of controlled intrusive light and heavy orthodontic forces: a microcomputed tomography scan study. Am J Orthod Dentofacial Orthop 2006; 130:639-47.

14. Weltman, B.; Vig, K.W.L.; Fields, H.W.; Shanker, S.; and Kaizar, E.E.: Root resorption associated with orthodontic tooth movement: A systematic review. Am J Orthod Dentofacial Orthop 2010; 137:462-76.

15. Brezniak, N.; and Wasserslein, A.: Orthodontically induced inflammatory root resorption. Part I: The basic science aspects. Angle Orthod 2002; 72:175-79.

16. Owman-Moll, P.; Kurol, J.;and Lundgren, D.: Effects of doubled orthodontic force magnitude on tooth movement and root resorption. An inter-individual study. Eur J Orthod 1996; 18: 141-50.

17. Mc Fadden, W.M.; Engstrom, C.; Engstrom, H.; and Anholm, J.M..: A study of the relationship between incisor intrusion and root shortening. Am J Orthod Dentofacial Orthop 1989;96:360-96.

18. Han, G.; Huang, S.; Von den Hoff, J.W.; Zeng, X.; and Kuijpers-Jagtman, A.M.: Root resorption after orthodontic intrusion and extrusion: An intra-individual study. Angle Orthod 2005; 75:912-18.

19. Kishnan, V.; and Davidovitch, Z.: Cellular, molecular and tissue level reactions to orthodontic force. Am J Orthod Dentofacial Orthop 2006; 129:469.e1-469.e32. 
Egyptian

Orthodontic Journal

20. Mulemann, H.R.; and Mazor, Z.S.: Gingivitis in Zurich school children. HelvOdontolActa 1958; 2:3.(quoted).

21. Plotnick, I.J.; Beresin, V.E.; and Simkins, A.B.: A technique for standardized serial dental radiographs. J Perodontol 1971; 42:297.

22. Yokota, E.T.; Miles, D.A.; and Newton, C.W.: Interpretation of periapical lesions using radiovisiography. Journal of Endo 1984; 20:490.

23. Yalcinkaya, S.; Kunzel, A.; Willer, S.R.; Thomas, M.; and Becker, J.: Oral Surg, Oral Medicine, Oral Pathology, Oral Radiology and Endodontics 2006; 101: 643.

24. Hans, M.G.; Kishiyama, C.; Parker, S.H.; Wolf, G.R.; and Noachtar, R.: Cephalometric evaluation of two treatment strategies for deep overbite correction. Angle Orthod 1994; 64:265-74.

25. Hong, R.K.; Hong, H.P.; and Koh, H.S.: Effect of reverse curve mushroom archwire on lower incisors in adult patients: a prospective study. Angle Orthod 2001; 71:425-32.

26. Firouz, M.; Zernik.J.; and Nanda, R.: Dental and orthopedic effects of high-pull headgear in treatment of class II, Division 1 malocclusion. Am J Orthod Dentofacial Orthop 1992; 102:197-205.

27. Sameshima, G.T.: Sinclair PM. Predicting and preventing root resorption: Part I. Diagnostic factors. Am J Orthod Dentofacial Orthop 2001; 119:505-10.

28. Chang, Y.I.I.; and Moon, S.C.: Cephalometric evaluation of the anterior open bite treatment. Am J Orthod Dentofacial Orthop 1999;115:29-38.

29. Yao, C.J.; Lee, J.; Chen, H.; Chang, Z.J.; Chang, H.;and Chen, Y.: Maxillary molar intrusion with fixed appliances and mini-implant anchorage studied in three dimensions. Angle Orthod 2005; 75:754-60.

30. Ng, J.; Major, P.W.; and Flores-Mir, C.: True molar intrusion attained during orthodontic treatment: A systematic review. Am J Orthod Dentofacial Orthop 2006; 130:709-14. 
Egyptian

Orthodontic Journal

31. Deguchi, T.; Kurosaka, H.; Oikawa, H.; Kuroda, S.; Takahashi, I.; Yamashiro, T.; and Takano-Yamamoto, T.: Comparison of orthodontic treatment outcomes in adults with skeletal openbite between conventional edgewise treatment and implant-anchored orthodontics. Am J Orthod Dentofacial Orthop 2011; 139:S60-8.

32. Proffit, W.R.; and Fields, H.W.: Treatment of orthodontic problems in preadolescent children: contemporary orthodontics, St Louis CV Mosby; 1986. p. 386-9.

33. Sherwood, K.H.; Burch, J.G.; and Thompson, W.: Intrusion of super erupted molars with titanium miniplate anchorage. Angle Orthod. 73:597-601, 2003.

34. Naumann, S.A.; Behrents, R.G.;and Buschang, P.H.: Vertical components of overbite change: A mathematical model. Am J OrthodDentofacialOrthop 2000; 117:486-95.

35. Melsen, B.; Agerback, N.; Erikson, J.; and Terp, S.: New attachment through dental treatment and orthodontic intrusion. Am J Orthod Dentofacial Orthop 1988; 94:104-116.

36. Murakami, T.; Yokota, Y.; and Takahama.: Periodontal changes after experimentally induced intrusion of the upper incisors in Macacafuscata monkeys. Am J Orthod Dentofacial Orthop 1998; 95:15-26.

37. Shoeib, M.; and Moustafa, Y.: Orthodontic treatment for periodontally compromised patients. Egyptian dental journal 1991; 37:31-46.

38. Rabie, A.M.; Zhou, D.; and Samman, N.: Ultrastructural identification of cells involved in the healing of the intramembranous and endochondral bone. Int J Oral Maxillofac Surg 1996; 25:383-88.

39. Zachrisson, B. Orthodontics and periodontics J. Lindhe, T. Karring, N.B. Lang (Eds), Clinical periodontology and implant dentistry, Munksgaard, Copenhagen 1997: 741-793.

40. Passanezi, E.;Janson, M.;Janson, G.;Sant Anna, A.P.; Roberto de Freitas, M.;and Henrigues, I.F.C.: Interdisciplinary treatment of localized juvenile periodontitis: A new perspective to an old problem. Am JOrthodDentofacialOrthop 2007; 131:268-76. 
41. Huser, M.C.;Baehni, P.C.; and Lang, R.: Effects on orthodontic bands on microbiologic and clinical parameters. Am J Orthod Dentofacial Orthop 1990; 97:213-18.

42. Levander, E.; and Malmgren, O.: long term follow-up of maxillary incisors with severe apical rootresorption. Eur J Orthod 2001; 22:85-92.

43. Levander, E.;Bajka, R.; and Malmgren, O.: Early radiographic diagnosis of apical root resorption during orthodontic treatment: a study of maxillary incisors. Eur J Orthod 1998; 20:57-63.

44. Proffit, W.R.; and Sellers, K.T.: The effect of intermittent forces on eruption of the rabbit incisor. J Dent Res 1986; 65:118-22.

45. Acar, A.; Canyürek, U.; Kocaaga, M.; and Erverd, N.: Continuous versus discontinuous force application and root resorption. Angle Orthod 1999; 69:159-63.

46. Ballard, D.J.; Jones, A.S.;Petocz, P.;and Darendeliler, M.A.: Physical properties of root cementum: Part 11. Continuous vs intermittent controlled orthodontic forces on root resorption. A microcomputed tomography study. Am J Orthod Dentofacial Orthop 2009; 136:8.e1-8.e8.

47. Harry, M.R.;and Sims, M.R.: Root resorption in bicuspid intrusion. A scanning electron microscope study. Angle Orthod 1982; 52:235-58.

48. Gürton, A.U.; Akin, E.; and karacay, S.:Intitial intrusion of the molars in the treatment of anterior open bite malocclusions in growing patients. Angle Orthod 2004; 74:454-64.

49. Hendrix, I.;Carels, C.; Kuijpers-Jagtman;and Hof, M.V.T.: A radiographic study of posterior apical root resorption in orthodontic patients. Am J Orthod Dentofacial Orthop 1994; 105:345-9.

50. Harris, D.A.; Jones, A.S.; and Darendeliler, M.A.: Physical properties of root cement: Part 8. Volumetric analysis of root resorption craters after application of controlled intrusive light and heavy orthodontic forces: a microcomputed tomography scan study. Am J Orthod Dentofacial Orthop 2006; 130:639-47. 
51. Kinzel, J.;Aberschek, P.;Mischak, I.;and Droschl, H.: Study of the extent of torque, protrusion and intrusion of the incisors in the context of class II, Division 2 treatment in adults. J OrofacOrthop 2002; 63:283-99.

52. Lupi, J.E.; Handelman, C.S.; and Sadowsky, C.: Prevalence and severity of apical root resorption and alveolar bone loss in orthodontically treated adults. Am J Orthod Dentofacial Orthop 1996; 109:28-37.

53. Vlaskalic, V.; Boyd, R.L.; and Baumrind, S.: Etiology and sequelae of rootresorption. Semin Orthod 1998; 4:124-31.

54. Brezniak, N.; and Wasserslein, A.: Orthodontically induced inflammatory root resorption. Part II: The clinical aspects. Angle Orthod 2002; $72: 180-84$.

55. Oppenhiem, A.: Human tissue response to orthodontic intervention of short and long duration. Am J Orthod 1942; 28:263-301.

56. Owman-Moll, P.;Kurol, J.; and Lundgren, D.: The effect of four-fold increased orthodontic force magnitude on tooth movement and root resorption. An inter-individual study. Eur J Orthod 1996; 18:287-94.

57. Jeon PD, Turley PK, Moon HB, and Ting K. Analysis of stress in the periodontium of the maxillary first molar with a three-dimensional finite element model. Am J Orthod Dentofacial Orthop 1999; 115:267-74. 